\title{
Dietary fiber and zinc additives on performance and intestinal health of Escherichia coli
}

\section{challenged piglets}

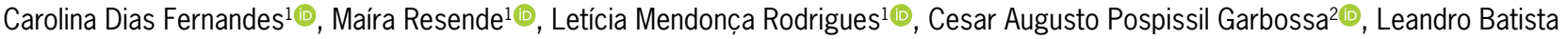

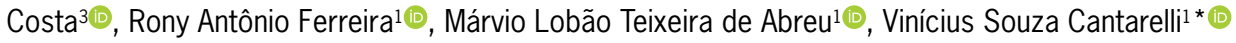

\author{
1Universidade Federal de Lavras - Depto. de Zootecnia, C.P. \\ 3037 - 37200-000 - Lavras, MG - Brasil. \\ 2Universidade de São Paulo - Depto. de Nutrição e Produção \\ Animal, Av. Duque de Caxias Norte, 225 - 13635-900 - \\ Pirassununga, SP - Brasil. \\ ${ }^{3}$ Pontifícia Universidade Católica do Paraná/Escola de \\ Ciências da Vida, R. Imaculada Conceição, 1155 - 80215- \\ 901 - Curitiba, PR - Brasil. \\ *Corresponding author <vinicius@dzo.ufla.br>
}

Edited by: Antonio Faciola

Received June 15, 2018

Accepted September 04, 2018
ABSTRACT: This study aimed to evaluate the effects of zinc oxide and a low level of encapsulated zinc oxide, with or without dietary fiber, on the performance and intestinal health of weaned piglets. A total of 112 piglets were used, divided into four treatment groups: basal diet with zinc oxide ( $\mathrm{ZnO})$; basal diet with zinc oxide and dietary fiber ( $\mathrm{ZnO}+\mathrm{DF})$; basal diet with encapsulated low zinc oxide ( $\mathrm{LZnOE}$ ); and basal diet with $\mathrm{LZnOE}$ and DF (LZnOE+DF). Piglets were challenged with $E$. coli K88+, weighed weekly and the fecal score was evaluated daily. One pig per pen was slaughtered to evaluate the production of volatile fatty acids, intestinal microbial populations, intestinal morphology, and digestibility. The encapsulated zinc resulted in lower body weight and average daily gain, but, when associated with dietary fiber, had similar results to zinc oxide. Until 49 days of age, zinc oxide reduced diarrhoea $(p<0.05)$. At 63 days of age the piglets subjected to $\mathrm{LZnOE}+\mathrm{DF}$ treatment had lower diarrhoea than the pigs subjected to $\mathrm{LZnOE}$ treatment but higher than the $\mathrm{ZnO}$ and the $\mathrm{ZnO}+\mathrm{DF}$ groups. Final weight and incidence of diarrhoea of pigs receiving $\mathrm{LZnOE}$ was worse than $\mathrm{ZnO}$. $\mathrm{LZnOE}$ associated with $\mathrm{DF}$ provided the same final weight of piglets from the $\mathrm{ZnO}$ group.

Keywords: nutrition, diarrhoea, jejunum, swine, weaning

\section{Introduction}

Postweaning diarrhoea syndrome (PWDS) is a recurrent problem during the transition from the maternity to the nursery phase, with strains of enterotoxigenic Escherichia coli as its main causative agents. PWDS is aggravated in early weaning conditions, when there is a reduction in the height and width of the intestinal villi and the activity of digestive enzymes (Wang et al., 2008).

Zinc oxide $(\mathrm{ZnO})$ and a portion of dietary fiber are potential additives with antimicrobial effects that can facilitate better adaptation to postweaning conditions (Pascoal et al., 2015). $\mathrm{ZnO}$ can be used in the diet of piglets to improve intestinal health and performance and may benefit intestinal morphology, resulting in increased villus density and height (Kwon et al., 2014). However, most of the $\mathrm{ZnO}$ delivered in high doses, from 1,500 to $3,000 \mathrm{ppm}$, is excreted in the feces, leading to environmental pollution (Hill et al., 2001). Thus, encapsulated zinc (EZ), which is released only after capsule digestion, can be used in lower doses, reducing the environmental impact (Shen et al., 2014).

Fibers are present in the postweaning diet when piglets start to be fed diets rich in plant products, and they play an important role in modulating the microbiota and intestinal morphology (Pascoal et al., 2015). According to Lindberg (2014), fiber, if it does not increase the viscosity, can be beneficial for piglets by increasing the lactobacilli:coliform ratio and decreasing the occurrence of weaning diarrhoea.

Considering all these beneficial effects and the possibility that fibers could also increase the activity of certain enzymes, such as lipase (Chen et al., 2015), their supply, along with EZ, may produce synergistic effects by speeding up lipid capsule degradation, releasing a greater amount of zinc at the beginning of the duodenum. Therefore, this study aimed to evaluate the effects of conventional $\mathrm{ZnO}$ and a low level of $\mathrm{EZnO}$, with or without dietary fibers, on the performance and intestinal health of weanling piglets.

\section{Materials and Methods}

\section{Animals and diets}

The experimental procedures were approved by the Ethics Committee on Animal Use of the University, protocol n ${ }^{\circ}$ 004/16.

A total of 112 piglets of commercial lineage, weaned at 21 days of age and with initial weight of 5.32 $\pm 1.31 \mathrm{~kg}$, were housed in a nursery unit with suspended pens in the experimental farm located at Lavras, Mi-

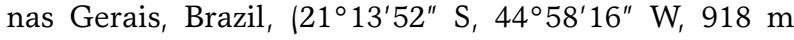
above sea level). The average temperature throughout the experiment was $26.34 \pm 3.01{ }^{\circ} \mathrm{C}$.

The diets were formulated to meet the minimum nutritional requirements, according to Rostagno et al. (2011), for three periods of the nursery phase: Pre-starter 1 ( 21 to 35 days of age), pre-starter 2 ( 36 to 49 days of age), and starter (50 to 63 days of age) (Table 1). To ensure isoenergetic and isoprotein diets, the inclusion of additives was offset by partial or total substitutions of the inert kaolin.

\section{Experimental design}

The experimental design was based on randomized blocks in a factorial scheme with four treatments, seven 
replicates, and four experimental piglets per replicate. Initial weight was the parameter used to define the blocks. Table 2 shows the four treatments used: 1) basal diet with pharmacological doses of $\mathrm{ZnO}(\mathrm{ZnO})$; 2) basal

Table 1 - Centesimal composition and nutritional values of the diets used in the experiment.

\begin{tabular}{|c|c|c|c|}
\hline Ingredients (\%) & Pre-starter 1 & Pre-starter 2 & Starter \\
\hline Corn & 40.66 & 49.84 & 67.87 \\
\hline Micronized soybean & 14.00 & 7.00 & 0.00 \\
\hline Soybean meal (CP† $46 \%$ ) & 15.00 & 22.00 & 25.00 \\
\hline Plasma spray dried & 5.00 & 2.50 & 0.00 \\
\hline Whey powder & 19.31 & 11.04 & 0.00 \\
\hline Soybean oil & 1.00 & 2.50 & 2.00 \\
\hline Dicalcium phosphate & 1.15 & 1.35 & 1.45 \\
\hline Mineral and vitamin premix ${ }^{1}$ & 0.10 & 0.12 & 0.00 \\
\hline Mineral and vitamin premix ${ }^{2}$ & 0.00 & 0.00 & 0.15 \\
\hline Limestone & 0.95 & 0.93 & 0.80 \\
\hline $\mathrm{NaCl}$ & 0.05 & 0.20 & 0.45 \\
\hline L-Lysine & 0.33 & 0.38 & 0.30 \\
\hline DL-Methionine & 0.18 & 0.17 & 0.07 \\
\hline L-Threonine & 0.14 & 0.15 & 0.06 \\
\hline L-Tryptophan & 0.03 & 0.02 & 0.00 \\
\hline L-Valine & 0.06 & 0.06 & 0.00 \\
\hline Kaolin & 2.04 & 1.74 & 1.85 \\
\hline \multicolumn{4}{|l|}{ Nutritional levels (calculated) } \\
\hline ME $\ddagger$ Swine $\left(k^{\prime}\right.$ al kg-1) & 3,472 & 3,395 & 3,227 \\
\hline CP (\%) & 21.96 & 20.30 & 17.00 \\
\hline Dig. Lysine (\%) & 1.45 & 1.33 & 1.00 \\
\hline Dig. Methionine (\%) & 0.44 & 0.42 & 0.30 \\
\hline Dig. Methionine + Cist. (\%) & 0.93 & 0.75 & 0.56 \\
\hline Dig. Threonine (\%) & 0.91 & 0.84 & 0.63 \\
\hline Dig. Tryptophan (\%) & 0.26 & 0.24 & 0.18 \\
\hline Dig. Valine (\%) & 1.00 & 0.92 & 0.71 \\
\hline Lactose (\%) & 14.00 & 8.00 & \\
\hline Calcium (\%) & 0.85 & 0.83 & 0.72 \\
\hline Available phosphorus (\%) & 0.50 & 0.45 & 0.36 \\
\hline Sodium (\%) & 0.28 & 0.23 & 0.20 \\
\hline \multicolumn{4}{|c|}{ 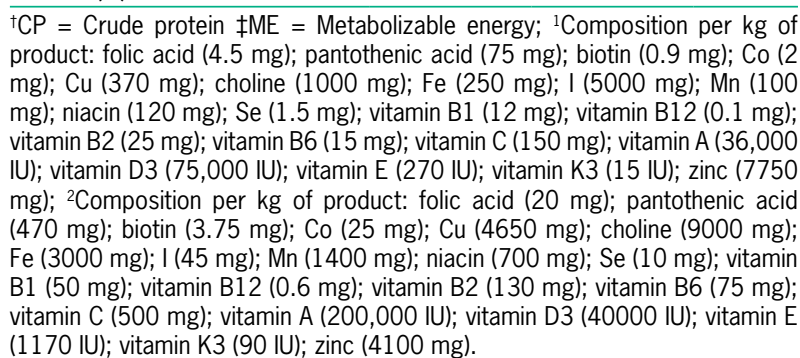 } \\
\hline
\end{tabular}

diet with pharmacological doses of $\mathrm{ZnO}$ and dietary fiber $(\mathrm{ZnO}+\mathrm{DF}) ; 3)$ basal diet with low level of encapsulated $\mathrm{ZnO}(\mathrm{LZnOE})$; 4) basal diet with encapsulated $\mathrm{Zn}$ and dietary fiber ( $\mathrm{LZnOE}+\mathrm{DF})$. The encapsulated $\mathrm{Zn}$ used was from Miavit $\mathrm{GmbH}$ and the dietary fiber was from Agromed Austria $\mathrm{GmbH}$. The fiber was not used from day 50 to 63 of the trial, because it is the recommendation of the manufacturer for commercial use in swine production systems.

\section{Experimental procedures}

The experiment lasted 42 days, and water and feed were supplied ad libitum. For the control of respiratory diseases, on the first day of the experiment, the piglets received a $0.15 \mathrm{~mL}$ dose of tulathromycin-based antibiotic, which acts just on the respiratory system, to standardize their immune response.

On the sixth and seventh days of the experiment (27 and 28 days of age), all animals were orally inoculated with $E$. coli. The animals received $1 \mathrm{~mL}$ of $10^{6} \mathrm{CFU}$ $\mathrm{mL}^{-1}$ of enterotoxigenic $E$. coli each day, for a total dose of $2 \mathrm{~mL}$, or $2 \times 10^{6} \mathrm{CFU}$, per piglet.

The bacterial inoculum used was obtained from the bacterial strain E. coli $\mathrm{K}^{+} 8^{+}(\mathrm{LT}+, \mathrm{STa}+$, and $\mathrm{STb}+)$. The strain was grown for $16 \mathrm{~h}$ at $37^{\circ} \mathrm{C}$ and then washed sequentially in phosphate-buffered saline (PBS) to reach a concentration of $10^{6}$ bacteria $\mathrm{mL}^{-1}$.

At 42 days of age, one animal per experimental unit was slaughtered via electronarcosis $(>300 \mathrm{~V}$ and $1.25 \mathrm{~A}$ for $6 \mathrm{~s})$, followed by exsanguination. The intestinal segment (jejunum) was collected for analysis of its morphology and cecal content, for the evaluation of volatile fatty acids, and for microbiological analysis.

\section{Performance and incidence of diarrhoea}

The piglets were weighed at 21,27,35,49, and 63 days of age for verification of their average daily gain (ADG). Twice a day, dietary intake was estimated by measuring leftovers and waste to calculate average daily feed intake (ADFI), and feed conversion rate (FCR).

The incidence of diarrhoea was assessed via fecal scoring, which was done every day in the morning by the same person. Feces were classified as normal (absence of diarrhoea) or as liquid and pasty stools (presence of diarrhoea). The incidence of diarrhoea was calculated based on the percentage of pens with animals

Table 2 - Experimental treatments.

\begin{tabular}{|c|c|c|c|}
\hline Treatments $^{1}$ & 21 to 35 days of age & 36 to 49 days of age & 50 to 63 days of age \\
\hline $\mathrm{ZnO}$ & 2500 ppm ZnO & 1500 ppm Zn0 & 1500 ppm ZnO \\
\hline \multirow{2}{*}{$\mathrm{ZnO}+\mathrm{DF}$} & 2500 ppm ZnO & 1500 ppm ZnO & 1500 ppm ZnO \\
\hline & 8000 ppm DF & 6000 ppm DF & \\
\hline $\mathrm{LZnOE}$ & 800 ppm Zn0 & 500 ppm Zn0 & 500 ppm ZnO \\
\hline \multirow{2}{*}{$\mathrm{LZnOE}+\mathrm{DF}$} & 800 ppm ZnO & 500 ppm ZnO & 500 ppm ZnO \\
\hline & 8000 ppm DF & 6000 ppm DF & \\
\hline
\end{tabular}

${ }^{1} \mathrm{ZnO}=$ Diet with pharmacological doses of $72 \% \mathrm{ZnO} ; \mathrm{ZnO}+\mathrm{DF}=$ Diet with pharmacological doses of $72 \% \mathrm{ZnO}$ and dietary fiber; LZnOE = Diet with low level of encapsulated ZnO; LZnOE + DF = Diet with low level of encapsulated ZnO and dietary fiber. 
affected with diarrhoea compared to the total number of observations made during a period. The periods from 21 to 27,21 to 35,21 to 42,21 to 49 , and 21 to 63 days of age were evaluated.

\section{Morphology of the jejunum}

After slaughter, a 5 -cm segment of the jejunum was collected at $2 \mathrm{~m}$ from the pylorus for morphological analysis. Samples were washed with a physiological solution and fixed in a $10 \%$ formaldehyde solution for $24 \mathrm{~h}$. They were then dehydrated, embedded in paraffin, and cut into sections $(4 \mu \mathrm{m})$ with a microtome. The sections were stained with haematoxylin and eosin, following the methods of Pluske et al. (1996).

Two sections were collected for each tissue sample (four cuts), and fifteen villi and fifteen crypts were measured per animal to evaluate villus height and crypt depth and to calculate the crypt depth/villus height ratio. Histological sections were analysed using an optical microscope with an attached camera and image analyser software.

\section{Digestibility}

From 42 to 44 days of age, feces were collected from all pigs of the pen to determine the digestibility of dry matter and crude protein. Chromium oxide $\left(\mathrm{Cr}_{2} \mathrm{O}_{3}\right)$ was used as a marker, and digestibility was calculated using the following formula: $\mathrm{DCP}=100-[100 \times / \mathrm{CD}$ / $\mathrm{CF} \times \mathrm{PF} / \mathrm{PD}$ )], where DCP: Digestibility apparent crude protein; $\mathrm{CD}$ : percentage of $\mathrm{Cr}_{2} \mathrm{O}_{3}$ in the diet; $\mathrm{CF}$ : percentage of $\mathrm{Cr}_{2} \mathrm{O}_{3}$ in the feces; $\mathrm{PF}$ : percentage of crude protein in the feces; PD: percentage of crude protein in the diet. The amount of chromium was measured using atomic absorption spectrometry.

\section{Microbiology}

For microbiological analyses, samples of cecal content were collected at slaughter. Analyses of the microbial populations were carried out using a selective culture method specific to $E$. coli, total coliforms, non$E$. coli coliform, and Lactobacillus spp. Colony counts $\left(\mathrm{CFU} \mathrm{g}{ }^{-1}\right)$ were submitted to logarithmic transformation $(\log 10)$ before statistical analysis.

\section{Volatile fatty acids}

The analysis of volatile fatty acids (acetic, propionic, and butyric acids) was performed on cecal contents collected after slaughter. To a 2 g sample of cecal content, $4 \mathrm{~mL}$ of formic acid (17\%) were added to extract and preserve the fatty acids present. Centrifugation was performed at 2,500 rpm, and the supernatant was stored at $-20^{\circ} \mathrm{C}$ until a gas chromatography analysis was carried out following the methodology described by Playne (1985).

\section{Statistical analysis}

The Shapiro-Wilk test was used to evaluate the normality of the data. When the variables did not present a normal distribution, data transformation was performed using PROC RANK. The data were analyzed using the SAS MIXED procedure appropriate to a randomized block design (initial weight) by applying a model with $\mathrm{ZnO}$ and fiber as an interaction. When the $\mathrm{F}$ test $(p<0.05)$ showed a significant difference, Tukey's test was used to compare the means of the interaction, For the independent effects of $\mathrm{ZnO}$ sources and fiber, the neabs were compared with $\mathrm{F}$ test $(p<0.05)$. To analyse the incidence of diarrhoea, a generalized linear model (binomial analysis) was performed using the GenMod procedure of SAS 9.3, with a significance level of 0.05. All data were analysed using the SAS software statistical package (SAS, v. 9.3).

\section{Results}

In the period from 21 to 27 days of age, the use of fiber increased the ADG ( $p=0.048)$ and feed intake ( $p$ $=0.001)$. During the same period, dietary fiber showed a tendency to increase body weight (BW) ( $p=0.058)$. However, FCR were not improved in this period. In the period from 21 to 35 days the treatments did not influence any performance variable. $\mathrm{ZnO}$ improved feed conversion from 21 to 42 days of age $(p=0.020)$ compared to LEZ. From 21 to 49 and 21 to 63 days of age, there was interaction between zinc and fiber $(p<$ $0.050), \mathrm{ZnO}$ improved feed intake compared to LZnOE in both periods; and from 21 to 63 days of age, the $\mathrm{LZnOE}$ resulted in worse BW $(p=0.004)$ when compared to the $\mathrm{ZnO}$; in a similar way the piglets of the LZnOE group had a lower ADG $(p=0.021)$ compared to the $\mathrm{ZnO}$ group (Table 3).

For the period from 21 to 27 days the treatments had no effect over the incidence of diarrhoea observed. From 21 to 35,21 to 42 , and 21 to 49 days of age, $\mathrm{ZnO}$ reduced the diarrhoea indices $(p<0.050)$ and, from 21 to 63 days of age, there was interaction between zinc and fiber: the LZnOE treatment group had a diarrhoea index greater than the LZnOE + DF group, but the $\mathrm{ZnO}$ and the $\mathrm{ZnO}+\mathrm{DF}$ treatment groups had the same diarrhoea index (Table 4). The $\mathrm{ZnO}$ and $\mathrm{ZnO}+$ DF treatments were more efficient in controlling diarrhoea $(p<0.05)$.

In this study, there was no effect of treatments on the microbe counts in the cecum for any bacterial species analysed (non-E. coli coliforms, E. coli, total coliforms, and Lactobacillus) (Table 5).

For cecal volatile fatty acid profiles a tendency was observed ( $p=0.077$ ) of fiber improving the amount of propionic acid compared with the pigs that did not receive fiber. For jejunal morphology no effect of the treatments was verified (Table 6).

Between the treatments, there were no significant differences in dry matter digestibility coefficients or in the apparent digestibility coefficients of crude protein (Table 7). 
Table 3 - Effects of the experimental diets on body weight (BW) (kg), average daily feed intake - ADFI (kg), average daily gain - ADG (kg), and feed conversion rate $-\mathrm{FCR}\left(\mathrm{kg} \mathrm{kg}^{-1}\right)$ of piglets weaned at 21 days of age ${ }^{\dagger}$.

\begin{tabular}{|c|c|c|c|c|c|c|c|c|}
\hline \multirow{2}{*}{ Variables } & \multicolumn{4}{|c|}{ Treatments } & \multirow{2}{*}{ SEM } & \multicolumn{3}{|c|}{$p$-value } \\
\hline & $\mathrm{ZnO}$ & $\mathrm{ZnO}+\mathrm{DF}$ & LZnOE & $\mathrm{LZnOE}+\mathrm{DF}$ & & Fiber & Zinc & Fiber $\times$ Zinc \\
\hline Initial weight & 5.327 & 5.328 & 5.329 & 5.320 & 0.003 & 0.253 & 0.165 & 0.104 \\
\hline \multicolumn{9}{|l|}{21 to 27 days } \\
\hline BW & 5.809 & 5.944 & 5.672 & 5.918 & 0.095 & 0.058 & 0.409 & 0.536 \\
\hline$A D G$ & 0.080 & 0.102 & 0.068 & 0.100 & 0.013 & 0.048 & 0.503 & 0.627 \\
\hline ADFI & 0.098 & 0.114 & 0.088 & 0.122 & 0.012 & 0.001 & 0.839 & 0.138 \\
\hline FCR & 1.382 & 1.286 & 1.055 & 1.250 & 0.094 & 0.500 & 0.141 & 0.173 \\
\hline \multicolumn{9}{|l|}{21 to 35 days } \\
\hline BW & 7.846 & 7.813 & 7.506 & 7.959 & 0.137 & 0.402 & 0.728 & 0.253 \\
\hline$A D G$ & 0.180 & 0.172 & 0.156 & 0.188 & 0.010 & 0.360 & 0.768 & 0.143 \\
\hline ADFI & 0.228 & 0.228 & 0.214 & 0.245 & 0.008 & 0.271 & 0.962 & 0.278 \\
\hline FCR & 1.360 & 1.327 & 1.358 & 1.377 & 0.014 & 0.884 & 0.581 & 0.523 \\
\hline \multicolumn{9}{|l|}{21 to 42 days } \\
\hline BW & 10.073 & 9.962 & 9.321 & 9.897 & 0.246 & 0.458 & 0.186 & 0.222 \\
\hline$A D G$ & 0.226 & 0.217 & 0.190 & 0.218 & 0.011 & 0.503 & 0.204 & 0.149 \\
\hline ADFI & 0.336 & 0.318 & 0.300 & 0.339 & 0.014 & 0.615 & 0.774 & 0.091 \\
\hline FCR & 1.495 & 1.492 & 1.594 & 1.561 & 0.042 & 0.591 & 0.020 & 0.649 \\
\hline \multicolumn{9}{|l|}{21 to 49 days } \\
\hline BW & 12.677 & 12.366 & 11.668 & 12.762 & 0.351 & 0.329 & 0.442 & 0.079 \\
\hline$A D G$ & 0.262 & 0.249 & 0.228 & 0.266 & 0.013 & 0.426 & 0.582 & 0.056 \\
\hline$\left.A D F\right|^{1}$ & $0.449 \mathrm{~A}$ & $0.421 \mathrm{AB}$ & $0.392 \mathrm{~B}$ & $0.445 \mathrm{AB}$ & 0.020 & 0.515 & 0.389 & 0.017 \\
\hline FCR & 1.722 & 1.694 & 1.693 & 1.706 & 0.010 & 0.982 & 0.833 & 0.693 \\
\hline \multicolumn{9}{|l|}{21 to 63 days } \\
\hline $\mathrm{BW}^{1}$ & $21.360 \mathrm{~A}$ & $20.070 A B$ & $19.310 \mathrm{~B}$ & $21.350 \mathrm{~A}$ & 0.833 & 0.455 & 0.449 & 0.004 \\
\hline $\mathrm{ADG}^{1}$ & $0.381 \mathrm{~A}$ & $0.352 A B$ & $0.343 \mathrm{~B}$ & $0.374 \mathrm{AB}$ & 0.015 & 0.947 & 0.513 & 0.021 \\
\hline $\mathrm{ADFl}^{1}$ & $0.664 \mathrm{~A}$ & $0.616 \mathrm{AB}$ & $0.598 \mathrm{~B}$ & $0.662 A B$ & 0.028 & 0.762 & 0.693 & 0.011 \\
\hline FCR & 1.745 & 1.743 & 1.753 & 1.697 & 0.019 & 0.446 & 0.605 & 0.487 \\
\hline
\end{tabular}

${ }^{\mathrm{ZnO}}=$ basal diet with $72 \% \mathrm{ZnO}$ at $2500 \mathrm{ppm}$ from days 21 to 35 and $1500 \mathrm{ppm}$ from days 36 to $63 ; \mathrm{ZnO}+\mathrm{DF}=$ basal diet with $72 \% \mathrm{Zn0}$ and dietary fiber at $2500 \mathrm{ppm}$ of $\mathrm{ZnO}$ and $8,000 \mathrm{ppm}$ of dietary fiber from days 21 to $35,1,500 \mathrm{ppm}$ of $\mathrm{ZnO}$ and $6000 \mathrm{ppm}$ of dietary fiber from days 36 to 49 and $1500 \mathrm{ppm} Z \mathrm{nO}$ from days 50 to $63 ; \mathrm{LZnOE}=$ basal diet with $800 \mathrm{ppm}$ of encapsulated ZnO from days 21 to 35 and $500 \mathrm{ppm}$ of encapsulated Zn from 36 to 63 days; LZnOE + DF $=$ basal diet with $800 \mathrm{ppm}$ of encapsulated $\mathrm{ZnO}$ and $8,000 \mathrm{ppm}$ of dietary fiber from days 21 to $35,500 \mathrm{ppm}$ of encapsulated $\mathrm{ZnO}$ and $6,000 \mathrm{ppm}$ of dietary fiber from days 36 to 49 and $500 \mathrm{ppm}$ of encapsulated $\mathrm{ZnO}$ from days 50 to 63 ; ${ }^{1}$ Means followed by different letters on the same line differ from each other based on Tukey's test $(p<0.05)$.

Table 4 - Effect of experimental diets on the incidence of diarrhoea (\% of compartments with diarrhoea) $)^{\dagger}$.

\begin{tabular}{|c|c|c|c|c|c|c|c|}
\hline \multirow{2}{*}{ Variables } & \multicolumn{4}{|c|}{ Treatments } & \multicolumn{3}{|c|}{$p$-value } \\
\hline & $\mathrm{ZnO}$ & $\mathrm{ZnO}+\mathrm{DF}$ & $\mathrm{LZnOE}$ & $\mathrm{LZnOE}+\mathrm{DF}$ & Fiber & Zinc & Fiber $\times$ Zinc \\
\hline 21 to 27 days & 34.2 & 34.2 & 40.0 & 34.3 & 0.724 & 0.724 & 0.729 \\
\hline 21 to 35 days & 27.5 & 25.3 & 42.9 & 37.4 & 0.436 & 0.005 & 0.798 \\
\hline 21 to 42 days & 21.4 & 22.9 & 39.3 & 33.6 & 0.666 & $<0.001$ & 0.386 \\
\hline 21 to 49 days & 24.3 & 27.5 & 46.6 & 37.6 & 0.515 & 0.001 & 0.088 \\
\hline 21 to 63 days ${ }^{1}$ & $18.8 \mathrm{~A}$ & $20.2 \mathrm{~A}$ & $38.3 \mathrm{C}$ & $27.2 \mathrm{~B}$ & 0.060 & 0.001 & 0.030 \\
\hline
\end{tabular}

${ }^{+} \mathrm{ZnO}=$ basal diet with $72 \% \mathrm{ZnO}$ at $2500 \mathrm{ppm}$ from days 21 to 35 and $1500 \mathrm{ppm}$ from days 36 to $63 ; \mathrm{ZnO}+\mathrm{DF}=$ basal diet with $72 \% \mathrm{ZnO}$ and dietary fiber at 2500 ppm of $\mathrm{ZnO}$ and $8000 \mathrm{ppm}$ of dietary fiber from days 21 to $35,1500 \mathrm{ppm}$ of $\mathrm{ZnO}$ and $6000 \mathrm{ppm}$ of dietary fiber from days 36 to 49 and $1500 \mathrm{ppm} \mathrm{ZnO}$ from days 50 to $63 ; \mathrm{LZnOE}=$ basal diet with $800 \mathrm{ppm}$ of encapsulated ZnO from days 21 to 35 and $500 \mathrm{ppm}$ of encapsulated ZnO from 36 to 63 days; LZnOE + DF = basal diet with $800 \mathrm{ppm}$ of encapsulated $\mathrm{ZnO}$ and 8,000 ppm of dietary fiber from days 21 to 35, $500 \mathrm{ppm}$ of encapsulated $\mathrm{ZnO}$ and 6,000 ppm of dietary fiber from days 36 to 49 and $500 \mathrm{ppm}$ of encapsulated $\mathrm{ZnO}$ from days 50 to 63 . 'Means followed by different letters on the same line differ from each other at a $5 \%$ probability level ( $p<0.05)$.

\section{Discussion}

In the present study, our results demonstrate that from 21 to 27 days of age, the inclusion of dietary fiber resulted in a better feed intake and ADG, in accordance with the literature (Hetland et al., 2004; Molist et al., 2009; Ramos et al., 2016). The dietary fiber intake might influence motility and transit time of digesta, thus interfering with the feed intake of animals (Mateos et al., 2006).

The greatest feed intake, ADG and BW observed in the period from 21 to 63 days of age in the pigs of $\mathrm{ZnO}$ experimental group when compared to the $\mathrm{LZnOE}$ treatment, coincided with a significant difference in 
Table 5 - Effects of experimental diets on colony forming unit (CFU $\log _{10}$ ) per g of faeces in the cecum for non-E. coli coliforms, E. coli, total coliforms, and Lactobacillus ${ }^{\dagger}$.

\begin{tabular}{|c|c|c|c|c|c|c|c|c|}
\hline \multirow{2}{*}{ Variables } & \multicolumn{4}{|c|}{ Treatments } & \multirow{2}{*}{ SEM } & \multicolumn{3}{|c|}{$p$-value } \\
\hline & $\mathrm{ZnO}$ & $\mathrm{ZnO}+\mathrm{DF}$ & LZnOE & $\mathrm{LZnOE}+\mathrm{DF}$ & & Fiber & Zinc & Fiber $\times$ Zinc \\
\hline Non-E. coli coliforms & 0.745 & 0.657 & 0.864 & 0.738 & 0.505 & 0.326 & 0.478 & 0.524 \\
\hline E. coli & 0.825 & 0.680 & 0.646 & 0.587 & 0.587 & 0.587 & 0.451 & 0.717 \\
\hline Total coliforms & 0.702 & 0.657 & 0.864 & 0.623 & 0.536 & 0.335 & 0.876 & 0.149 \\
\hline Lactobacillus & 7.471 & 7.801 & 7.523 & 7.468 & 0.166 & 0.254 & 0.514 & 0.365 \\
\hline
\end{tabular}

${ }^{\mathrm{ZnO}}=$ basal diet with $72 \% \mathrm{ZnO}$ at 2,500 ppm from days 21 to 35 and $1,500 \mathrm{ppm}$ from days 36 to $63 ; \mathrm{ZnO}+\mathrm{DF}=$ basal diet with $72 \% \mathrm{ZnO}$ and dietary fiber at $2,500 \mathrm{ppm}$ of $\mathrm{ZnO}$ and $8,000 \mathrm{ppm}$ of dietary fiber from days 21 to $35,1,500 \mathrm{ppm}$ of $\mathrm{ZnO}$ and $6,000 \mathrm{ppm}$ of dietary fiber from days 36 to 49 and $1500 \mathrm{ppm} \mathrm{ZnO}$ from days 50 to 63; LZnOE = basal diet with $800 \mathrm{ppm}$ of encapsulated ZnO from days 21 to 35 and $500 \mathrm{ppm}$ of encapsulated ZnO from 36 to 63 days; LZnOE + DF $=$ basal diet with $800 \mathrm{ppm}$ of encapsulated $\mathrm{ZnO}$ and $8,000 \mathrm{ppm}$ of dietary fiber from days 21 to $35,500 \mathrm{ppm}$ of encapsulated $\mathrm{ZnO}$ and 6,000 ppm of dietary fiber from days 36 to 49 and 500 ppm of encapsulated ZnO from days 50 to 63 .

Table 6 - Effects of experimental diets on cecal volatile fatty acid (VFA) profiles (nM) and on villus height $=\mathrm{VH}(\mu \mathrm{m})$, $\mathrm{crypt}$ depth $=\mathrm{CD}(\mu \mathrm{m})$, and villus height/crypt depth ratio $=\mathrm{VH} / \mathrm{CD}^{\dagger}$.

\begin{tabular}{|c|c|c|c|c|c|c|c|c|}
\hline \multirow{2}{*}{ Variables } & \multicolumn{4}{|c|}{ Treatments } & \multirow{2}{*}{ SEM } & \multicolumn{3}{|c|}{$p$-value } \\
\hline & $\mathrm{ZnO}$ & $\mathrm{ZnO}+\mathrm{DF}$ & $\mathrm{LZnOE}$ & $\mathrm{LZnOE}+\mathrm{DF}$ & & Fiber & Zinc & Fiber $\times$ Zinc \\
\hline Acetic acid & 681.138 & 771.669 & 716.981 & 677.298 & 77.686 & 0.414 & 0.499 & 0.800 \\
\hline Propionic acid & 324.849 & 385.400 & 301.849 & 382.468 & 42.636 & 0.077 & 0.560 & 0.550 \\
\hline Butyric acid & 149.372 & 146.573 & 105.806 & 156.023 & 23.438 & 0.264 & 0.404 & 0.218 \\
\hline \multicolumn{9}{|c|}{ Morphometry of the jejunum } \\
\hline $\mathrm{VH}$ & 342.862 & 286.436 & 313.667 & 326.849 & 18.729 & 0.251 & 0.761 & 0.116 \\
\hline$C D$ & 345.497 & 318.328 & 342.183 & 348.613 & 16.459 & 0.612 & 0.382 & 0.332 \\
\hline $\mathrm{VH} / \mathrm{CD}$ & 1.138 & 0.950 & 1.016 & 1.014 & 0.068 & 0.141 & 0.569 & 0.202 \\
\hline
\end{tabular}

${ }^{\mathrm{ZnO}}=$ basal diet with $72 \% \mathrm{ZnO}$ at 2,500 ppm from days 21 to 35 and $1,500 \mathrm{ppm}$ from days 36 to $63 ; \mathrm{ZnO}+\mathrm{DF}=$ basal diet with $72 \% \mathrm{ZnO}$ and dietary fiber at $2500 \mathrm{ppm}$ of $\mathrm{ZnO}$ and $8,000 \mathrm{ppm}$ of dietary fiber from days 21 to $35,1,500 \mathrm{ppm}$ of $\mathrm{ZnO}$ and $6000 \mathrm{ppm}$ of dietary fiber from days 36 to 49 and $1500 \mathrm{ppm} \mathrm{ZnO}$ from days 50 to $63 ; \mathrm{LZnOE}=$ basal diet with $800 \mathrm{ppm}$ of encapsulated ZnO from days 21 to 35 and 500 ppm of encapsulated ZnO from 36 to 63 days; LZnOE + DF $=$ basal diet with $800 \mathrm{ppm}$ of encapsulated $\mathrm{ZnO}$ and $8,000 \mathrm{ppm}$ of dietary fiber from days 21 to $35,500 \mathrm{ppm}$ of encapsulated $\mathrm{ZnO}$ and $6,000 \mathrm{ppm}$ of dietary fiber from days 36 to 49 and 500 ppm of encapsulated $\mathrm{ZnO}$ from days 50 to 63 .

Table 7 - Effect of treatments on dry matter digestibility coefficients (DMDC) and crude protein apparent digestibility coefficients (CPDC) ${ }^{\dagger}$.

\begin{tabular}{|c|c|c|c|c|c|c|c|c|}
\hline \multirow{2}{*}{ Variables } & \multicolumn{4}{|c|}{ Treatments $^{1}$} & \multirow{2}{*}{ SEM } & \multicolumn{3}{|c|}{$p$-value } \\
\hline & $\mathrm{ZnO}$ & $\mathrm{ZnO}+\mathrm{DF}$ & LZnOE & $\mathrm{LZnOE}+\mathrm{DF}$ & & Fiber & Zinc & Fiber $\times$ Zinc \\
\hline$\overline{D M D C}$ & 81.473 & 80.774 & 80.549 & 81.002 & 0.772 & 0.986 & 0.684 & 0.505 \\
\hline CPDC & 72.664 & 70.568 & 70.004 & 72.838 & 1.463 & 0.624 & 0.931 & 0.140 \\
\hline
\end{tabular}

${ }^{\mathrm{ZnO}}=$ basal diet with $72 \% \mathrm{ZnO}$ at 2,500 ppm from days 21 to 35 and $1,500 \mathrm{ppm}$ from days 36 to $63 ; \mathrm{ZnO}+\mathrm{DF}=$ basal diet with $72 \% \mathrm{ZnO}$ and dietary fiber at $2,500 \mathrm{ppm}$ of $\mathrm{ZnO}$ and $8,000 \mathrm{ppm}$ of dietary fiber from days 21 to $35,1,500 \mathrm{ppm}$ of $\mathrm{ZnO}$ and $6,000 \mathrm{ppm}$ of dietary fiber from days 36 to 49 and 1,500 ppm ZnO from days 50 to $63 ; \mathrm{LZnOE}$ = basal diet with $800 \mathrm{ppm}$ of encapsulated ZnO from days 21 to 35 and $500 \mathrm{ppm}$ of encapsulated ZnO from 36 to 63 days; LZnOE + DF $=$ basal diet with $800 \mathrm{ppm}$ of encapsulated $\mathrm{ZnO}$ and $8,000 \mathrm{ppm}$ of dietary fiber from days 21 to 35, $500 \mathrm{ppm}$ of encapsulated $\mathrm{ZnO}$ and 6,000 ppm of dietary fiber from days 36 to 49 and $500 \mathrm{ppm}$ of encapsulated $\mathrm{ZnO}$ from days 50 to 63 .

the diarrhoea indices between the groups that received $\mathrm{LZnOE}$ or $\mathrm{ZnO}$. This can be explained by the fact that diarrhoea stimulates an immune response in piglets, leading to an increase in proinflammatory cytokines, such as interleukin-1 $\beta$ (IL-1 $\beta$ ), interleukin-6 (IL-6), and tumour necrosis factor- $\alpha$ (TNF- $\alpha$ ), which are anorexigenic (Broussard et al., 2001). Sargeant et al. (2010) studied the effect of $\mathrm{ZnO}$ on these inflammatory factors and concluded that the inclusion of $\mathrm{ZnO}$ in the diet reduces the formation of proinflammatory cytokines, leading to an improvement in performance. The reduction of anorexigenic factors may be associated with greater consumption by the animals, and $\mathrm{ZnO}$ may reduce these factors.

However, our findings differ from Shen et al. (2014), who tested the difference between high and low $\mathrm{ZnO}$ inclusion levels and increasing LZnOE inclu- sion levels, testing a maximum level of $1140 \mathrm{mg} \mathrm{kg}^{-1}$ of zinc, and did not observe any influence of the treatments on performance variables. The other performance variables were not affected by the treatments, corroborating the results found by Bondzio et al. (2013), Davin et al. (2013), O'Shea et al. (2014), and Liu et al. (2014).

During the periods from 21 to 49 and 63 days of age, the groups that received $\mathrm{LZnOE}$ had a higher diarrhoea incidence than the zinc oxide groups. In the LZnOE + DF treatment, the insoluble fibers included may have increased enzymatic activity, including that of lipase (Chen et al., 2015), favoring digestion of the lipid capsule and consequently releasing more $\mathrm{Zn}$ in the intestine. Thus, an intermediate incidence of diarrhoea can be observed in this group from 21 to 63 days of age, as well as a tendency for this to occur from 21 to 49 days of age. 
Dietary fibers can also have prebiotic effects in pigs due to interactions with the gut micro-environment and gut-associated immune system, which increased the amount of beneficial microorganisms and consequently microbial enzymes which may contribute to a better digestion and use of the nutrients (Lee et al., 2016).

Zinc oxide, both in its conventional and its encapsulated form, is known to reduce diarrhoea rates in weaned piglets (Shen et al., 2014). One of the mechanisms of action of this additive is to exert a protective effect on the enterocytes, inhibiting adherence and invasion by $E$. coli (Roseli et al., 2003).

Another mechanism of action of $\mathrm{Zn}$ that prevents diarrhoea is the reduction of chloride excretion into the mucosa of the colon. When inhibiting potassium-conducting basolateral channels by altering the transport of ions in mucosal tissue, fluid secretion is reduced, contributing to the dehydration of the digesta in the lumen (Medani et al., 2012). This dehydration may limit the activity of pathogenic bacteria.

A number of studies have shown the success of LZnOE in the control of postweaning diarrhoea in animals challenged with $E$. coli $\mathrm{K}^{\circ} 8^{+}$, but it must be noted that, in these studies, the animals started to receive LZnOE at ages older than 28 days (Shen et al., 2014), 30 days (Kim et al., 2015), or even 35 days (Kwon et al., 2014).

For the LZnOE to be released into the lumen, the digestion of its lipid capsule must occur. It is known that pancreatic lipase increases in activity from 0 to 35 days of age and reaches a mature level at 28 days of age. In addition, weaning causes a decrease in the activity of this enzyme $(\mathrm{Gu}$ and $\mathrm{Li}, 2003)$. Thus, the LZnOE may have been inefficient during the first days of the experiment because of the low lipase activity at this stage, since the capsule is composed of lipids of plant origin. Poor digestion of the lipid capsule may have reduced the amount of $\mathrm{Zn}$ released in the LZnOE and LZnOE + DF treatments compared to the other treatments. Low lipase activity after weaning at 21 days $(\mathrm{Gu}$ and $\mathrm{Li}, 2003)$ may explain the results showing that the LZnOE and LZnOE + DF treatment groups had greater difficulty in recovering from the challenge. As the LZnOE is less easily liberated in the gastrointestinal tract of the piglets after weaning, they could not benefit from the advantages that $\mathrm{ZnO}$ provides to them.

Diarrhoea is related to, among other factors, the intestinal microbiota, which in this study was not affected by the treatments. These results corroborate those found by O'Shea et al. (2014). In addition, the lack of effect of the treatments on the microbiota of the cecum contributed to the lack of variation of the volatile fatty acid profiles and intestinal morphology, corroborating the results of O'Shea et al., 2014; Kwon et al., 2014 and Liu et al. (2014). Other studies have also indicated that coliform bacteria are not affected by diets with high $\mathrm{Zn}$ levels (Broom et al., 2006) or that these populations may even be increased (Hojberg et al., 2005). This may occur because of decreased competition with Lactobacillus, as these may be reduced in the presence of high $\mathrm{Zn}$ concentrations (Starke et al., 2014), although this was not proven by this study.

Acetic, propionic and butyric acids are the major end products of fiber degradation in the hindgut of pigs, similar to our findings Wang et al. (2004) found that insoluble fiber increased the levels of propionate.

It is known that longer villi in the jejunum increase the activity of saccharide-related enzymes (Pluske et al., 1996). It can therefore be deduced that the same occurs with the activity of other enzymes of the brush border, directly affecting the digestibility of the diet; however, as had been seen previously, in this study, there was no effect of the treatments on villus height in the jejunum, which helps to explain the lack of effect of the treatments on nutrient digestibility.

Low levels of $\mathrm{ZnO}$ encapsulated with dietary fiber guaranteed piglets the same final weight as did high levels of $\mathrm{ZnO}$. However, the LZnOE isolate did not mitigate the incidence of diarrhoea and worse performance of pigs after the E. Coli challenge. The interaction of those compounds should be further evaluated to better understand the effects as a tool for improving pig performance.

\section{Acknowledgments}

These studies were sponsored by Biosen Agro Industrial Ltda. and the authors would like to express gratitude to the company.

\section{Authors' Contributions}

Conceptualization: Fernandes, D.C.; Resende, M.; Rodrigues, L.M.; Garbossa, C.A.P.; Costa L.B.; Ferreira, R.A.; Abreu, M.L.T.; Cantarelli, V.S. Data acquisition: Fernandes, D.C.; Resende, M.; Rodrigues, L.M.; Garbossa, C.A.P. Data Analysis: Garbossa, C.A.P. Design of methodology: Fernandes, D.C.; Resende, M.; Rodrigues, L.M.; Garbossa, C.A.P.; Costa L.B.; Ferreira, R.A.; Abreu, M.L.T.; Cantarelli, V.S. Writing and editing: Fernandes, D.C.; Resende, M.; Rodrigues, L.M.; Garbossa, C.A.P.; Cantarelli, V.S.

\section{References}

Bondzio, A.; Pieper, R.; Gabler, C.; Weise, C.; Schulze, P.; Zentek, J.; Einspanier, R. 2013. Feeding low or pharmacological concentrations of zinc oxide changes the hepatic proteome profiles in weaned piglets. Plos One 8: e81202.

Broom, L.J.; Miller, H.M.; Kerr, K.G.; Knapp, J.S. 2006. Effects of zinc oxide and Enterococcus faecium SF68 dietary supplementation on the performance, intestinal microbiota and immune status of weaned piglets. Research in Veterinary Science 80: 45-54. 
Broussard, S.R.; Zhou, J.H.; Venters, H.D.; Bluthé, R.M.; Freund, G.G.; Johnson, R.W.; Dantzer, R.; Kelley, K.W. 2001. At the interface of environment-immune interactions: cytokine and growth-factor receptors. Journal of Animal Science 89: E268-E284.

Chen, H.; Mao, X.; Yin, J.; Yu, B.; He, J.; Che, L.; Yu, J.; Huang, Z.; Zheng, P.; Michiels, J.; De Smet, S.; Chen, D. 2015. Comparison of jejunal digestive enzyme activities, expression of nutrient transporter genes, and apparent fecal digestibility in weaned piglets fed diets with varied sources of fiber. Journal of Animal and Feed Sciences 24: 41-47.

Davin, R.; Manzanilla, E.G.; Klasing, K.C.; Pérez, J.F. 2013. Effect of weaning and in-feed high doses of zinc oxide on zinc levels in different body compartments of piglets. Journal of Animal Physiology and Animal Nutrition 97: 6-12.

Gu, X.; Li, D. 2003. Fat nutrition and metabolism in piglets: a review. Animal Feed Science and Technology 109: 151-170.

Hetland, H.; Choct, M.; Svihus, B. 2004. Role of insoluble nonstarch polysaccharides in poultry nutrition. World Poultry Science Journal 60: 415-422

Hill, G.M. 2001. Minerals and mineral utilization in swine. p. 173195. In: Chiba, L.I., ed. Sustainable swine nutrition. John Wiley, New York, NY, USA.

Hojberg, O.; Canibe, N.; Poulsen, H.D.; Hedemann, M.S.; Jensen, B.B. 2005. Influence of dietary zinc oxide and copper sulfate on the gastrointestinal ecosystem in newly weaned piglets. Applied and Enviromental Microbiology 71: 2267-2277.

Kim, S.J.; Kwon, C.H.; Park, B.C.; Lee, C.Y.; Han, J.H. 2015. Effects of a lipid-encapsulated zinc oxide dietary supplement, on growth parameters, and intestinal morphology in weanling pigs artificially infected with enterotoxigenic Escherichia coli. Journal of Animal Science and Technology 57: 1-5.

Kwon, C.H.; Lee, C.Y.; Han, S.J.; Kim, S.J.; Park, B.C.; Jang, I.; Han, J.H. 2014. Effects of dietary supplementation of lipidencapsulated zinc oxide on colibacillosis, growth and intestinal morphology in weaned piglets challenged with enterotoxigenic Escherichia coli. Animal Science Journal 85: 805-813.

Lee, S.J.; Kim J.Y.; Park, N.H.; Awji, E.G.; Suh, J.W.; Park, S.C. 2016. Effect of dietary fiber source on the growth performance and intestinal microflora in piglets. The International Journal of Applied Research in Veterinary Medicine 14: 135-142.

Lindberg, J.E. 2014. Fiber effects in nutrition and gut health in pigs. Journal of Animal Science and Biotechnology 5: 1-7.

Liu, P.; Pieper, R.; Rieger, J.; Vahjen, W.; Davin, R.; Plendl, J.; Meyer, W.; Zentek, J. 2014. Effect of dietary zinc oxide on morphological characteristics, mucin composition and gene expression in the colon of weaned piglets. Plos One 9: e91091.

Mateos, G.G.; Martín, F.; Latorre, M.A.; Vicente, B.; Lazaro, R. 2006. Inclusion of oat hulls in diets for young pigs based on cooked maize or cooked rice. Animal Science 82: 57-63.

Medani, M.; Bzik, V.A.; Rogers, A.; Collins, D.; Kennelly, R.; Winter, D.C.; Brayden, D.J.; Baird, A.W. 2012. Zinc sulphate attenuates chloride secretion in human colonic mucosae in vitro. European Journal of Pharmacology 696: 166-171.

Molist, F.; Gómez de Segura, A.; Gasa, A.; Hermes, R.G.; Manzanilla, E.G.; Anguita, M.; Pérez, J.F. 2009. Effects of the insoluble and soluble dietary fiber on the physicochemical properties of digesta and microbial activity in early weaned piglets. Animal Feed Science and Technology 149: 346-353.
O'Shea, C.J.; McAlpine, P.; Sweeney, T.; Varley, P.F.; O'Doherty, J.V. 2014. Effect of the interaction of seaweed extracts containing laminarin and fucoidan with zinc oxide on the growth performance, digestibility and faecal characteristics of growing piglets. British Journal of Nutrition 111: 798-807.

Pascoal, L.A.F.; Thomaz, M.C.; Watabase, P.H.; Ruiz, U.S.; Amorim, A.B.; Daniel, E.; Silva, S.Z. 2015. Purified cellulose, soybean hulls and citrus pulp as a source of fiber for weaned piglets. Scientia Agricola 72: 400-410.

Playne, M.J. 1985. Determination of ethanol, volatile fatty acids, lactic acid, and succinic acids in fermentation liquids by gas chromatography. Journal of the Science of Food and Agriculture 36: 638-644.

Pluske, J.R.; Williams, I.H.; Aherne, F.X. 1996. Maintenance of villous height and crypt depth in piglets by providing continuous nutrition after weaning. Animal Science 62: 131144.

Ramos, G.F.; Júnior, C.D.S.; Oliveira, J.A.; Vasconcelos, T.S.; Budiño, F.E.L.; Ruiz, U.S. 2016. Performance, diarrhea frequency, feces production and costs of diets with increasing levels of pineapple byproducts in weaned piglets. Arquivo Brasileiro de Medicina Veterinária e Zootecnia 68: 1505-1515 (in Portuguese, with abstract in English).

Roseli, M.; Finamore, A.; Garaguso, I.; Britti, M.S.; Mengheri, E. 2003. Zinc oxide protects cultured enterocytes from the damage induced by Escherichia coli. Journal of Nutrition 133: 4077-4082.

Rostagno, H.S.; Albino, L.F.T.; Donzele, J.L.; Gomes, P.C.; Oliveira, R.F.; Lopes, D.C.; Ferreira, A.S.; Barreto, S.L.T.; Euclides, R.F. 2011. Brazilian Tables for Poultry and Swine, Composition of Food and Nutritional Needs = Tabelas Brasileiras para Aves e Suínos: Composição de Alimentos e Exigências Nutricionais. 3ed. UFV, Viçosa, MG, Brazil (in Portuguese).

Sargeant, H.R.; McDowall, K.J.; Miller, H.M.; Shaw, M.A. 2010. Dietary zinc oxide affects the expression of genes associated with inflammation: transcriptome analysis in piglets challenged with ETEC K88. Veterinary Immunology and Immunopathology 137: 120-129.

Shen, J.; Chen, Y.; Wang, Z.; Zhou, A.; He, M.; Mao, L.; Zou, H.; Peng, Q.; Xue, B.; Wang, L.; Zhang, X.; Wu, S.; Lv, Y. 2014. Coated zinc oxide improves intestinal immunity function and regulates microbiota composition in weaned piglets. British Journal of Nutrition 111: 2123-2134.

Starke, I.C.; Pieper, R.; Neumann, K.; Zentek, J.; Vahjen, W. 2014. The impact of high dietary zinc oxide on the development of the intestinal microbiota in weaned piglets. FEMS Microbiology Ecology 87: 416-427.

Wang, J.; Chen, L.; Li, P.; Li, X.; Zhou, H.; Wang, F.; Li, D.; Yin, Y.; Wu, G. 2008. Gene expression is altered in piglet small intestine by weaning and dietary glutamine supplementation. The Journal of Nutrition 138: 1025-1032.

Wang, J.F.; Zhu, Y.H.; Li, D.F.; Wang, Z.; Jensen, B.B. 2004. In vitro fermentation of various fiber and starch sources by pig fecal inocula. Journal of Animal Science 82: 2615-2622. 